\title{
ANALISIS KEMUDAHAN AKSES TERHADAP KEPERCAYAAN MASYARAKAT PADA BANK SYARIAH (STUDI BANK BRI SYARIAH KCP PALABUHANRATU)
}

\section{THE ANALYSIS OF THE EASE ACCESS TO PUBLIC TRUST IN SYARIAH BANK (STUDY BANK BRI SYARIAH KCP PALABUHANRATU SUKABUMI)}

\author{
Mustika Delima1a; Metti Paramita²; \\ 1aProgram Studi Perbankan Syariah Fakultas Ekonomi Islam Universitas Djuanda, Jl. Tol \\ Ciawi No. 1 Bogor Kode Pos 16720, E-mail: mustikadelima15@gmail.com \\ 2Program Studi Ekonomi Syariah Fakultas Ekonomi Islam Universitas Djuanda, Jl. Tol \\ Ciawi No. 1 Bogor Kode Pos 16720
}

\begin{abstract}
This study aims to determine community expectations regarding access to Islamic banks and to find out the ease access to public trust in Islamic banks. This research method uses quantitative descriptive with chi square data analysis tecniques. The results showed that the chi value was greater than the chi table value, which means that Ho was rejected and $\mathrm{H} 1$ was accepted, meaning that Palabuhanratu sub-district using Islamic banks already felt easy to access, so the community trusted in BRI Syariah Bank KCP Palabuhanratu.
\end{abstract}

Keywords: Ease, Access, Costumer Trust, Islamic Bank.

\begin{abstract}
ABSTRAK
Penelitian ini bertujuan untuk mengetahui harapan masyarakat terkait akses pada bank syariah dan untuk mengetahui kemudahan akses terhadap kepercayaan masyarakat pada bank syariah. Metode penelitian ini menggunakan deskriptif kuantitatif dengan teknik analisis data chi square. Hasil penelitian menunjukan nilai chi hitung lebih besar dari nilai chi tabel yang berarti Ho ditolak dan H1 diterima, artinya masyarakat kecamatan Palabuhanrtu yang menggunakan bank syariah sudah merasa mudah terkait akses, sehingga masyarakat percaya terhadap bank BRI Syariah KCP Palabuhanratu.
\end{abstract}

Kata Kunci : Kemudahan, Akses, Kepercayaan Nasabah, Bank Syariah

Mustika Delima. 2019. Analisis Kemudahan Akses Terhadap Kepercayaan Masyarakat Pada Bank Syariah (Studi Pada Bank BRI Syariah KCP Palabuhanratu). Nisbah: Jurnal Perbankan Syariah 5 (1): 75-82

\section{PENDAHULUAN}

Pertumbuhan perkembangan teknologi berbanding lurus dengan perkembangan gaya hidup masa kini. Semakin luasnya informasi yang didapatkan dari berbagai media baik cetak maupun elektronik, membuat perkembangan gaya hidup masyarakat sekarang ini sangat membutuhkan akses informasi yang cepat untuk mengakomodir kebutuhan informasi mereka. Mobilitas dan kebutuhan akses informasi inilah yang membuat gaya 
hidup masyarakat sekarang tidak terlepas dari perangkat teknologi dimasa sekarang ini. Hal ini menggambarkan kebutuhan informasi masyarakat sekarang ini sangatlah penting dan membutuhan akses informasi yang lebih cepat dan tepat. Kebutuhan informasi inilah yang membuat teknologi dimasa kini terus berkembang guna memenuhi kebutuhan informasi masyarakat yang sangat tinggi (Habibi; Zaky, 2014: 1).

Rendahnya akses informasi bank syariah pada masyarakat dapat menyebabkan ketidakpahaman pada bank syariah. Akses informasi tidak akan efektif apabila tidak ada keterbukaan dan kemudahan dalam memperoleh akses informasi yang lebih luas. Tidak teraksesnya layanan finansial disebabkan ketersediaan layanan yang biasanya sangat jauh dari pedesaan dan mahalnya ongkos menabung di bank. Pada akses fasilitas, kurangnya peralatan yang up to date pada kantor bank syariah. Jaringan kantor bank syariah diperlukan dalam rangka perluasan jangkauan pelayanan kepada masyarakat. Jaringan bank syariah diharapkan dapat meningkatkan kompetisi kearah peningkatan kualitas pelayanan dan mendorong inovasi produk dan jasa bank syariah (Muis, 2001: 161). Faktor aksesibilitas juga ikut mempengaruhi kenaikan minat masyarakat pada bank syariah. Tersedianya fasilitas-fasilitas yang menunjang kelancaran dalam transaksi, nasabah tentunya akan merasa puas dan akan terus menggunakan jasa bank tersebut (Azhar, 2014: 3 ).

Untuk meyakinkan kepercayaan bank syariah terhadap masyarakat yaitu hendaknya bank tetap mempertahankan layanan yang sesuai dengan harapan nasabah sehingga konsumen tetap memilih bank syariah sebagai alternatif utama dalam menabung. Kemudian pihak bank harus dapat membuktikan secara nyata dalam hal fasilitas (tangibles) seperti tempat duduk dan ruangan yang nyaman, serta sejuk, ventilasi udara yang memadai serta adanya informasi yang lengkap tentang bentuk pelayanan yang dapat dilayani pihak bank. Dengan minimnya akses pada bank syariah membuat masyarakat kurang percaya, oleh sebab itu peneliti tertarik mengangkat judul Analisis Kemudahan Akses Terhadap Kepercayaan Masyarakat pada Bank Syariah.

\section{MATERI DAN METODE}

\section{Pengertian Bank Syariah}

Pasal 1 ayat (2) UU Nomor. 21 Tahun 2008 Tentang Perbankan Syariah, bank adalah badan usaha yang menghimpun dana dari masyarakat dalam bentuk simpanan dan menyalurkannya kepada masyarakat dalam bentuk kredit atau bentuk lainnya untuk meningkatkan taraf hidup rakyat. Bank Islam atau selanjutnya disebut dengan bank syariah, adalah bank yang beroperasi dengan tidak mengandalkan pada bunga. Bank syariah juga dapat diartikan sebagai lembaga keuangan/perbankan yang operasional dan produknya dikembangkan berdasarkan Al-Quran dan Hadist Nabi SAW (Wardiah, 2013 : 75-76).

\section{Akses Bank Syariah}

Menurut Kamus Besar Bahasa Indonesia akses adalah jalan masuk. Pengertian akses adalah kemampuan untuk mendapatkan manfaat dari sesuatu atau hak untuk memperoleh sesuatu kekuasaan (Ribot dan Peluso, 2003) dalam Sita (2014). Definisi akses adalah hak untuk memasuki, memakai dan memafaatkan kawasan atau zonazona tertentu (Schlager dan Ostrom, 1992) dalam (Sulistyo, 2014). Menurut Menon (2014) dalam Setyawan dan Japarianto (2014) melakukan sebuah penelitian mengenai aksesibilitas dan dari penelitian tersebut bahwa aksesibilitas menentukan tingkat 
kenyamanan konsumen sehingga aksesibilitas menjadi faktor yang menentukan perilaku konsumen. Dapat dijelaskan bahwa aksesibilitas adalah kemudahan untuk melakukan pendekatan.

a. Informasi

Menurut Krismiaji (2015: 15) informasi adalah data yang telah diorganisasi dan telah memiliki kegunaan dan manfaat. Susanto (2008: 38) menyatakan informasi adalah hasil dari pengolahan data yang memberikan arti dan manfaat. Sedangkan menurut Kusrini (2007:7) informasi adalah data yang sudah diolah menjadi sebuah bentuk yang berarti pengguna, yang bermanfaat dalam pengambilan keputusan saat ini atau mendukung sumber informasi.

b. Fasilitas

Fasilitas adalah sumber daya fisik yang ada sebelum suatu jasa dapat ditawarkan kepada konsumen (Tjiptono,1997) dalam (Budi, 2010), sedangkan menurut Sulastiyono (2006) fasilitas adalah penyediaan perlengkapan-perlengkapan fisik untuk memberikan kemudahan kepada para tamu dalam melaksanakan aktivitasaktivitasnya atau kegiatan-kegiatannya, sehingga kebutuhan-kebutuhan tamu dapat terpenuhi. Segala fasilitas yang ada yaitu kelengkapan, kondisi fasilitas, serta kebersihan fasilitas harus diperhatikan terutama yang berkaitan erat dengan yang dirasakan atau didapat konsumen secara langsung. Konsumen memang harus diberikan kepuasan oleh perusahaan, sebab apabila konsumen tidak merasa puas maka akan meninggalkan perusahaan dan menjadi pelanggan pesaing.

c. Layanan

Definisi pelayanan adalah suatu aktivitas atau serangkaian aktivitas yang bersifat tidak kasat mata yang terjadi sebagai akibat adanya interaksi antara konsumen dengan karyawan atau hal-hal lain yang disebabkan oleh perusahaan pemberi pelayanan yang dimaksudkan untuk memecahkan permasalahan konsumen (Ratminto; Winarsih, 2005: 2). Pelayanan juga didefinisikan sebagai "kegiatan yang dilakukan oleh seseorang atau sekelompok orang dengan landasan faktor material melalui sistem prosedur dan dengan metode tertentu dalam rangka usaha memenuhi kepentingan orang lain sesuai haknya" (Moenir, 2008: 27).

d. Lokasi

Menurut Lupiyoadi (2001: 61) dalam Tyas, Setiawaan (2012: 9) mendefinisian lokasi adalah tempat dimana perusahaan harus berkemas melakukan operasi. Pemilihan lokasi mempunyai fungsi yang strategis karena dapat ikut menentukan tercapainya tujuan badan usaha.

Hubungan lokasi terhadap keputusan pembelian menurut Ma'ruf (2005:114) dalam Tyas, Setiwan (2012: 9) menyatakan bahwa lokasi memiliki pengaruh terhadap keputusan pembelian dimana lokasi yang tepat, sebuah gerai akan lebih sukses dibandingkan gerai lainnya yang berlokasi kurang strategis, meskipun keduanya menjual produk yang sama.

\section{Kepercayaan}

Ba dan Pavlou (2002) dalam Farizi (2014) mendefinisikan kepercayaan sebagai suatu penilaian hubungan dengan orang lain yang melakukan transaksi tertentu sesuai dengan harapan dalam sebuah lingkungan yang penuh ketidakpastian. Butler (1991) dalam Widiastuti (2010) menjelaskan bahwa ada beberapa faktor kondisi yang dapat menyebabkan kepercayaan itu timbul diantaranya, keleluasaan, ketersediaan, kompetensi, konsistensi, pelaku adil, integritas, loyalitas, keterbukaan, kepercayaan secara keseluruhan, janji akan pemenuhan kebutuhan, dan penerimaan. 


\section{Metode Penelitian}

Jenis penelitian yang digunakan pada penelitian ini adalah deskriptif kuantitatif. Metode ini digunakan untuk mengetahui kemudahan akses terhadap kepercayaan masyarakat pada bank BRI Syariah KCP Palabuhanratu. Populasi penelitian ini adalah nasabah bank BRI Syariah KCP Palabuhanratu dengan sampel penelitian sebanyak 100 orang responden yang dihimpun dengan menggunakan stratified sampling.

adalah data primer dengan menggunakan data primer dengan menggunakan kuesioner yang disebarkan kepada para responden. Data sekunder diperoleh dari beberapa literatur penunjang penelitian dan data dari instansi terkait (Arikunto, 2010:157).

\section{HASIL DAN PEMBAHASAN}

\section{Demografi Responden}

Karakteristik responden dalam penelitian ini dapat dijelaskan pada tabel berikut ini.

\section{Tabel 1.}

\section{Karakteristik Responden}

\begin{tabular}{|c|c|c|}
\hline Karkteristik & Uraian & Jumlah \\
\hline \multirow[t]{2}{*}{ Jenis Kelamin } & Lak-laki & 55 \\
\hline & Perempuan & 45 \\
\hline \multirow[t]{4}{*}{ Usia } & $<20$ tahun & 1 \\
\hline & 20-30 tahun & 80 \\
\hline & 30-40 tahun & 12 \\
\hline & $>40$ tahun & 7 \\
\hline \multirow{4}{*}{$\begin{array}{l}\text { Pendidikan } \\
\text { Terakhir }\end{array}$} & SD & 4 \\
\hline & SMP & 4 \\
\hline & SMA & 41 \\
\hline & Diploma/Sarjana & 51 \\
\hline \multirow[t]{5}{*}{ Pekerjaan } & Pelajar/Mhs. & 45 \\
\hline & PNS & 2 \\
\hline & Wiraswasta & 11 \\
\hline & Pegawai Swasta & 27 \\
\hline & Lainnya & 15 \\
\hline \multirow{2}{*}{$\begin{array}{l}\text { Lama } \\
\text { Menabung }\end{array}$} & $<1$ Tahun & 17 \\
\hline & 2 Tahun & 14 \\
\hline
\end{tabular}

\begin{tabular}{llc}
\hline 3 Tahun & 11 \\
& 4 Tahun & 4 \\
& $>4$ Tahun & 14 \\
\hline Rp.<1.000.000., & 32 \\
Pendapatan & Rp.1.000.000 s/d & 27 \\
Perbulan & Rp. 3000.000., & \\
Rp. 3.100.000 s/d & 18 \\
Rp. 5000.000,- & \\
& $>5.100 .000 .-$ & 21 \\
& Lainnya & 2
\end{tabular}

Sumber: Hasil Penelitian, 2018

\section{Analisis Data}

Uji Validitas

Dari 24 pernyataan yang dituangkan dalam kuesioner, setelah dilakukan uji validitas lebih dari $r$ tabel yaitu $\geq 0,196$. Hasil ini menunjukkan bahwa seluruh variabel yang digunakan dalam kuesioner penelitian ini untuk mengetahui kepercayaan masyarakat pada Bank Syariah dengan variabel informasi, fasilitas, layanan dan lokasi adalah valid.

Uji Reliabilitas

Pengujian reliabilitas bertujuan untuk mengetahui sejauh mana hasil suatu pengukuran dapat dipercaya (Azwar, 2012:87).

Tabel 2. Reliability Statistics

\begin{tabular}{cc}
$\begin{array}{l}\text { Cronbach's } \\
\text { Alpha }\end{array}$ & $\begin{array}{l}\text { N of } \\
\text { Items }\end{array}$ \\
\hline 942 & 24 \\
\hline Sumber: Data Diolah, 2018 \\
Nilai Cronbach's
\end{tabular}

942>0,60 maka dapat disimpulkan bahwa 24 pernyataan dalam kuesioner ini adalah reliabel.

Skala Likert

Statistik deskripsi skala likert adalah tahapan yang menjabarkan hasil dari kuesioner yang diisi oleh responden. 
Tabel 3. Penjabaran Skala Likert

\begin{tabular}{|c|c|c|c|c|c|}
\hline \multicolumn{2}{|c|}{ Kode } & \multicolumn{2}{|c|}{$\begin{array}{l}\mathrm{M}=\sum(f x) / \\
N\end{array}$} & & \\
\hline \multicolumn{2}{|l|}{ A1 } & \multicolumn{2}{|c|}{3,15} & & \\
\hline \multicolumn{2}{|l|}{ A2 } & \multicolumn{2}{|c|}{3,12} & & \\
\hline \multicolumn{2}{|l|}{ A3 } & \multicolumn{2}{|c|}{3,27} & & \\
\hline \multicolumn{2}{|l|}{ A4 } & \multicolumn{2}{|c|}{3,05} & & \\
\hline \multicolumn{6}{|c|}{ Sumber: Data Diolah, 2018} \\
\hline \multicolumn{6}{|c|}{$\begin{array}{l}\text { Uji ini digunakan untuk menguji } \\
\text { seberapa besar taraf signifikansi yang } \\
\text { diperoleh dari jawaban responden agar } \\
\text { hasil yang diperoleh dapat teruji secara } \\
\text { akurat. Berikut perhitungan dan analisis } \\
\text { untuk kemudahan akses terhadap } \\
\text { kepercayaan nasabah pada bank syariah: } \\
\text { a. Informasi }\end{array}$} \\
\hline \multicolumn{6}{|c|}{$\begin{array}{c}\text { Tabel } 4 . \\
\text { Hasil Uji Chi-Square Tentang Informasi } \\
\text { terhadap Kepercayaan Masyarakat pada } \\
\text { Bank Syariah }\end{array}$} \\
\hline Respon & Fo & Fh & $\begin{array}{l}\text { (Fo- } \\
\text { Fh) }\end{array}$ & $\begin{array}{l}\text { (Fo- } \\
\text { Fh) }\end{array}$ & $\frac{(F o-F h)^{2}}{F h}$ \\
\hline $\begin{array}{l}\text { Sangat } \\
\text { Setuju }\end{array}$ & 28 & 33,3 & $-5,3$ & 28,09 & 0,84 \\
\hline Setuju & 63 & 33,3 & 29.7 & 882,09 & 26,4 \\
\hline Tidak Setuju & 7 & 33,3 & -26.3 & 691,69 & 20,7 \\
\hline $\begin{array}{l}\text { Sangat tidak } \\
\text { setuju }\end{array}$ & 0 & 0 & 0 & 0 & 0 \\
\hline Total & 100 & 100 & 0 & $\begin{array}{c}1.601,8 \\
7\end{array}$ & 47,94 \\
\hline
\end{tabular}

Sumber: Hasil Penelitian (diolah Tahun 2018)

Berdasarkan hasil uji pada tabel 4, maka diperoleh perhitungan chi-square hitung sebesar 47,94 dengan $\mathrm{dk}=\mathrm{n}-1=4$ $1=3$ dengan taraf signifikan sebesar $5 \%$, maka diperoleh chi-square tabel sebesar 7,815. Diketahui bahwa nilai chi-square hitung lebih besar dari nilai chi tabel $(47,94>7,815)$. Dengan demikian Ho ditolak dan $\mathrm{H} 1$ diterima atau dapat dikatakan informasi bank syariah terdapat pengaruh terhadap kepercayaan masyarakat. Dalam skala penafsiran, kemudahan informasi terhadap kepercayaan masyarakat pada bank syariah, "setuju" dengan nilai penafsiran sebesar 3,15. Hal ini sesuai dengan nilai chi square hitung lebih besar dibandingkan dengan nilai Chi Tabel
$(47,94>7,815)$. Hal ini dimungkinkan terjadi karena sekitar (28 responden) menyatakan sangat setuju sedangkan menyatakan setuju (63 responden) dan tidak setuju (7 responden). Berdasarkan hasil penelitian yang dilakukan kepada responden, yang menyatakan tidak setuju yaitu sebagian kecil responden menyatakan bahwa informasi pada bank syariah kurang jelas dan tidak mendalam.

Pernyataan yang diajukan diantaranya adalah mengenai informasi yang diberikan bank syariah, pengetahuan karyawan dalam memberikan informasi pada nasabah tentang produknya, media yang digunakan untuk melakukan promosi. Diantara semua responden, rata-rata menjawab pilihan setuju terhadap pernyataan-pernyataan yang diajukan. Responden berpendapat bahwa saat ini bank syariah memberikan informasi kepada nasabah dengan baik, serta dinilai sudah sesuai dengan kebutuhan nasabah, dan informasi tersebut dapat dihandalkan, meskipun beberapa responden menyatakan bahwa kenyataannya informasi yang diberikan bank syariah belum sepenuhnya lengkap dan mendalam, sehingga hal tersebut mempengaruhi tingkat kepercayaan masyarakat kecamatan Palabuhanratu untuk menggunakan jasa Bank BRI Syariah KCP Palabuhanratu.

Berdasarkan hal tersebut, diketahui bahwa sebenarnya responden dalam hal ini mengetahui informasi yang diberikan bank syariah namun hanya sekilas saja tidak mendalam. Sehingga responden memilih untuk menjawab "tidak setuju" walaupun mereka sesungguhnya mengetahui tentang bank syariah tersebut. 


\section{b. Fasilitas}

Tabel 5

Hasil Uji Chi-Square Tentang Fasilitas terhadap Kepercayaan Masyarakat pada Bank Syariah

\begin{tabular}{|c|c|c|c|c|c|c|}
\hline $\begin{array}{l}\mathbf{N} \\
\mathbf{0}\end{array}$ & Respon & Fo & Fh & $\begin{array}{l}\text { (Fo- } \\
\text { Fh) }\end{array}$ & $\begin{array}{l}\text { (Fo- } \\
\text { Fh) }\end{array}$ & $\frac{(\text { Fo-Fh })^{2}}{\text { Fh }}$ \\
\hline 1 & $\begin{array}{l}\text { Sangat } \\
\text { Setuju }\end{array}$ & 24 & 25 & -1 & 1 & 0,04 \\
\hline 2 & Setuju & 65 & 25 & 40 & 1.600 & 64 \\
\hline 3 & Tidak Setuju & 10 & 25 & -15 & 225 & 9 \\
\hline \multirow[t]{2}{*}{4} & $\begin{array}{l}\text { Sangat tidak } \\
\text { setuju }\end{array}$ & 1 & 25 & -24 & 576 & 23,04 \\
\hline & Total & 100 & 100 & 0 & 2.402 & 96,08 \\
\hline
\end{tabular}

Sumber: Hasil Penelitian (diolah Tahun 2018)

Berdasarkan hasil uji pada tabel 5, maka diperoleh perhitungan chi-square hitung sebesar 96,08 dengan $\mathrm{dk}=\mathrm{n}-1=4-$ $1=3$ dengan taraf signifikan sebesar 5\%, maka diperoleh chi-square tabel sebesar 7,815. Diketahui bahwa nilai chi-square hitung lebih besar dari nilai chi tabel $(96,08>7,815)$. Dengan demikian Ho ditolak dan $\mathrm{H} 1$ diterima atau dapat dikatakan bahwa fasilitas bank syariah terdapat pengaruh terhadap kepercayaan masyarakat. Dalam skala penafsiran, kemudahan fasilitas terhadap kepercayaan masyarakat pada bank syariah, "setuju" dengan nilai penafsiran sebesar 3,12. Hal ini sesuai dengan nilai chi square hitung lebih besar dibandingkan dengan nilai Chi Tabel $(96,08>7,815)$. Hal ini dimungkinkan terjadi karena sekitar (33 responden) menyatakan sangat setuju sedangkan menyatakan setuju (62 responden) dan tidak setuju (7 responden).

Pernyataan yang diajukan mengenai bangunan fisik bank syariah, peralatan yang modern, area parkir yang memadai, rata-rata responden menyatakan setuju. Responden berpendapat bahwa saaat ini bank syariah memberikan kenyamanan terhadap nasabah, menyediakan area parkir yang memadai, memiliki ruang pelayanan yang bersih, meskipun beberapa responden menyatakan bahwa sebenarnya bank syariah tidak memiliki gedung yang luas, ruang tunggu dan kursi yang memadai. Mereka beranggapan bahwa sebaiknya bank syariah meningkatkan fasilitas bangunan fisik agar terlihat baik dan terasa nyaman oleh masyarakat. Setelah dilakukan penelitian, bank tempat praktisi tersebut sudah memberikan yang terbaik kepada nasabahnya.

\section{c. Layanan}

Tabel 6.

Hasil Uji Chi-Square Tentang Layanan terhadap Kepercayaan Masyarakat pada Bank Syariah

\begin{tabular}{|c|c|c|c|c|c|c|}
\hline $\begin{array}{l}\mathbf{N} \\
\mathbf{O}\end{array}$ & Respon & Fo & Fh & $\begin{array}{l}\text { (Fo- } \\
\text { Fh) }\end{array}$ & $\begin{array}{l}\text { (Fo- } \\
\text { Fh) }\end{array}$ & $\frac{(\mathrm{Fo}-\mathrm{Fh})^{2}}{\mathrm{Fh}}$ \\
\hline 1 & $\begin{array}{l}\text { Sangat } \\
\text { Setuju }\end{array}$ & 33 & 25 & 8 & 64 & 2,56 \\
\hline 2 & Setuju & 62 & 25 & 37 & 1.369 & 54,76 \\
\hline 3 & $\begin{array}{l}\text { Tidak } \\
\text { Setuju }\end{array}$ & 4 & 25 & -21 & 441 & 17,64 \\
\hline 4 & $\begin{array}{l}\text { Sangat } \\
\text { tidak } \\
\text { setuju }\end{array}$ & 1 & 25 & -24 & 576 & 23,04 \\
\hline & Total & 100 & 100 & 0 & 2.450 & 98 \\
\hline
\end{tabular}

Sumber: Hasil Penelitian (diolah Tahun 2018)

Berdasarkan hasil perhitungan chi square seperti yang ditunjukkan pada tabel 6, maka nilai chi square hitung $=98$, dengan derajat kebebasan $(\mathrm{dk})=\mathrm{n}-1=4$ $1=3$. Berdasarkan $\mathrm{dk}=3$ dengan taraf signifikan sebesar 5\%, maka diperoleh nilai Chi Tabel $=7,815$. Diketahui bahwa nilai Chi hitung lebih besar dari nilai Chi Tabel $(98>7,815)$. Dengan demikian Ho ditolak dan $\mathrm{H} 1$ diterima atau dapat dikatakan bahwa masyarakat menilai pelayanan bank syariah adalah "baik". Dalam skala penafsiran sebesar 3,27. Hal ini sesuai dengan uji chi square yang didapatkan hasil nilai Chi hitung lebih besar dibandingkan dengan Chi Tabel (98 > 7,815). Hal ini terjadi responden menyatakan sangat setuju (33 responden), responden menyatakan setuju (62 responden), responden menyatakan tidak setuju (4 responden) dan sangat tidak setuju (1 responden).

Berdasarkan hasil penelitian yang telah dilakukan terhadap responden yang menyatakan tidak setuju dikarenakan responden kurang berinteraksi dengan bank syariah, hal ini 
karena ketika responden berinteraksi dengan bank syariah, pelayanannya yang cukup lama dan tidak tepat waktu. Nasabah bank syariah yang diberikan kuesioner tentang layanan, berpendapat setuju terhadap pernyataan-pernyataan yang dipaparkan oleh peneliti dalam kuesioner. Pernyataan-pernyataan tersebut diantaranya responden setuju bahwa bank syariah selalu siap sedia memberikan bantuan kepada nasabah, karyawan melayani nasabah secara secara Islami, dan lain sebagainya. Jawaban setuju dari setiap responden menyatakan bahwa bank syariah sudah memberikan layanan yang baik.

\section{d. Lokasi}

Tabel 7.

Hasil Uji Chi-Square Tentang Lokasi terhadap Kepercayaan masyarakat pada Bank Syariah

\begin{tabular}{|c|c|c|c|c|c|c|}
\hline $\begin{array}{l}\mathbf{N} \\
\mathbf{0}\end{array}$ & Respon & Fo & Fh & $\begin{array}{l}\text { (Fo- } \\
\text { Fh) }\end{array}$ & $\begin{array}{l}\text { (Fo- } \\
\text { Fh) }\end{array}$ & $\frac{(\text { Fo-Fh })^{2}}{F h}$ \\
\hline 1 & Sangat Setuju & 23 & 33,3 & $-10,3$ & 106,09 & 3,18 \\
\hline 2 & Setuju & 59 & 33,3 & 25,7 & 660,49 & 19,83 \\
\hline 3 & Tidak Setuju & 18 & 33,3 & $-15,3$ & 234.09 & 7,02 \\
\hline 4 & $\begin{array}{l}\text { Sangat tidak } \\
\text { setuju }\end{array}$ & 0 & 0 & 0 & 0 & 0 \\
\hline & Total & 100 & 100 & 0 & $\begin{array}{c}1.000 \\
76\end{array}$ & 30,03 \\
\hline
\end{tabular}

Sumber: Hasil Penelitian (diolah tahun 2018)

Berdasarkan hasil perhitungan chi square seperti yang ditunjukkan pada tabel 7, maka nilai chi square hitung = 30,03 dengan derajat kebebasan $(\mathrm{dk})=\mathrm{n}$ $1=4-1=3$. Berdasarkan $\mathrm{dk}=3$ dengan taraf signifikan sebesar 5\%, maka diperoleh nilai Chi Tabel $=7,815$. Diketahui bahwa nilai Chi hitung lebih besar dari nilai Chi Tabel $(30,03>7,815)$. Dengan demikian Ho ditolak dan H1 diterima atau dapat dikatakan bahwa masyarakat menilai lokasi bank syariah adalah mudah untuk dijangkau. Dalam skala penafsiran sebesar 3,05. Hal ini sesuai dengan uji chi square yang didapatkan hasil nilai Chi hitung lebih besar dibandingkan dengan Chi Tabel $(30,03>7,815)$. Hal ini terjadi responden menyatakan sangat setuju (23 responden), responden menyatakan setuju (59 responden), responden menyatakan tidak setuju (18 responden).

Hasil dari kuesioner menunjukkan bahwa lokasi bank syariah mudah dijangkau, bank syariah berada ditempat yang lingkungannya nyaman, dan berada pada lokasi yang dapat dilihat dengan jelas oleh masyarakat, sehingga dapat mempermudah nasabah menggunakan jasa bank syariah. Tetapi sebagaian masyarakat menyatakan tidak setuju, karena jaringan perusahaan yang dimiliki bank syariah tidak banyak, sehingga dianggap kurang efisien.

\section{KESIMPULAN DAN IMPLIKASI}

Setelah dilakukan penelitian mengenai analisis kemudahan akses terhadap kepercayaan masyarakat pada bank syariah, penulis dapat mengambil kesimpulan sebagai berikut:

1. Harapan masyarakat terkait akses pada bank syariah adalah meningkatkan akses bank syariah kepada masyarakat, seperti meningkatkan informasi secara lengkap, mendalam dan rinci, walaupun sebagian besar masyarakat menilai bank syariah memiliki informasi yang jelas, meningkatkan fasilitas yang lengkap dan memadai, memberikan pelayanan yang baik, cepat, tepat dan sesuai etika perbankan, lokasi yang mudah dijangkau dan strategis bagi nasabah yang akan bertransaksi di bank syariah.

2. Kemudahan akses terhadap kepercayaan masyarakat pada bank syariah adalah semakin akses ditingkatkan kemudahannya, maka akan semakin memudahkan masyarakat bertransaksi pada bank syariah, sehingga dengan adanya akses yang baik maka masyarakat akan percaya pada bank syariah. 


\section{DAFTAR PUSTAKA}

Buku:

Arikunto, S. (2000). Manajemen Penelitian . Jakarta: Rineka Cipta.

Arsyad, Azhar. (2014). Media Pembelajaran. Jakarta: PT Rajagrafindo Persada.

Azwar, S. 2012. Reliabilitas dan Validitas. Yogyakarta: Pustaka Pelajar

Kountur, R. (2007). Metode Penelitian untuk penulisan Skripsi dan Tesis, edisi revisi. Jakarta: PPM.

Muis, A. (2001). Komunikasi Islami. Bandung: Remaja Rosdaarya.

Sita, R. (2014). Pertarungan Kuasa Dan Legitimasi Klaim atas Sumber Daya Hutan. Bogor: Institut Pertanian Bogor.

Wardiah, M. L. (2013). Dasar-Dasar Perbakan. Bandung: Pustaka Setia.

\section{Jurnal:}

Budi, M. S., \& Ukudi. (2007). Pengaruh Kualitas Layanan, Kepercayaan dan Komitmen terhadap Loyalitas Nasabah. Jurnal Bisnis dan Ekonomi, Volume 14, Nomor 2.

Sulistyo, E., \& dkk. (2014, Desember). Zona Tradisional Wujud Desentralisasi Pengelolaan Taman Nasional Di Indonesia: Pemikiran Konseptual. Jurnal Kebijakan Kehutanan, Volume 11, Nomor 3.

Wardayati, S. M. (2011). Implikasi Shariah Governance Terhadap Reputasi dan Kepercayaan Bank Syariah. Walisongo, Volume 19, Nomor 1.

Zakiy, M. (2017). Pengaruh Kualitas Layanan Terhadap Loyalitas Nasabah Bank Syariah dengan Kepuasan Nasabah Sebagai Variabel Intervening. Jurnal Ekonomi dan Bisnis Islam, Volume 3, Nomor 1.

\section{Undang-Undang dan Peraturan}

Undang-Undang No. 21 Tahun 2008, Tentang Perbankan Syariah, Pasal 1 butir 23 